\title{
PROCESS IN CONTEMPORARY VISUAL ART AS A PARADIGM SHIFT IN THE VISUAL ART EDUCATION: PERSPECTIVE OF CREATIVITY
}

\author{
Sonja VUK (1) ${ }^{1, *}$, Maja BOSNAR (10 ${ }^{2}$ \\ ${ }^{1}$ Art Education Department, Academy of Fine Arts, University of Zagreb, \\ Ilica 85, 10000 Zagreb, Croatia \\ ${ }^{2}$ Theoretical Department, Faculty of Fine Arts, University of Arts in Belgrade, \\ Pariska 16, 11000 Belgrade, Serbia
}

Received 3 May 2020; accepted 17 December 2020

\begin{abstract}
The authors discuss contemporary visual art, its creation processes and their implementation in art education in primary and secondary/grammar school. Changing the paradigm of studying from "fine to visual arts" within art education is a process itself. Visual art, which involves a participatory and new media art, is also concerned with processes that establish unique relationships between subjects and their effect on the real life of the participants or audience. It is no longer enough to deal with aesthetic concepts, but it is necessary to use art forms to create everyday life, and deal with ethical concepts. Transferring these processes into education connects students' creative activities and their everyday life context, so that they can learn how to create social and personal relationships by using images. Experimental research in grammar school affirms the importance of teaching topics as are socially and politically engaged art or artistic activism, mediated by new media. Action research in elementary school affirms proposed style of art education as an acceptable way of transferring the way of thinking from visual art, especially a participatory and new media art, to the process of education as a discovering problems in society and offering solutions represented by visual forms.
\end{abstract}

Keywords: art education, contemporary visual art, creativity, primary school, process, secondary/ grammar school.

\section{Introduction}

Contemporary visual art, that is postmodern and post-post modern art, as a part of visual culture is generally no different from the so-called popular/mass art (Carroll, 1998) where a work of art resembles another product of popular culture (Groys, 2006). The interactive process between such a work of art and the audience creates new social relations in everyday life situations, therefore visual art is a mediator among people, just as art education is (Freedman, 2003). Visual art, especially a participatory and new media art, is thus concerned with

*Corresponding author. E-mail: sonja.vuk@gmail.com

Copyright (c) 2021 The Author(s). Published by Vilnius Gediminas Technical University

This is an Open Access article distributed under the terms of the Creative Commons Attribution License (http://creativecommons. org/licenses/by/4.0/), which permits unrestricted use, distribution, and reproduction in any medium, provided the original author and source are credited. 
the creation of new social relations. This makes visual art a living matter, a process. The art process involves an analysis of steps that enable the reconstruction of the creative process and, also, dematerialization of an art object. The process is a modification of the state and position of bodies, objects, spatial positions, shapes of matter and energy that takes place over time and has a structure of events (Šuvaković, 2012).

The process as the basis of participatory art, establishes certain unique relationships of subjects initiated by the artists themselves and examining the effects of these relationships on the real life of the participants (Milevska, 2006). Participatory art directly engages the audience in the creative process so that it becomes an active participant in the event. Participatory practices in art are examples of the ways in which art and social aspects are connected and become closer, and take over social patterns from different social and cultural aspects with the aim of establishing critical thinking about society, local environment, culture, while being politically engaged (Stanković, 2014).

The process is also one of the key features of new media art, and its other characteristics are: creativity in solving conceptual problems; inclusion of context; participation, role play, creation of new relationships; art as communication, interaction and performance, which implies "mixing fine art, photography, video, installation, interactive screen" (Baudrillard, 2006, p. 102); cognition of reality in the form of images; an outlook that encompasses the whole; a total immersion; tactility; algorithmic approach; a game; practical skills development etc. (Strehovec, 2003).

Visual art curriculum is often inconsistent with a contemporary context of students characterized by new technologies and social forces (Kirby, 2009). When designing contemporary plans of study, it is necessary to start from students' conceptual environment (Freedman, 2003), so art education should be considered as a process analogous to art (Kettel, 2004, also see Alsaggar \& Shukran, 2014), whereas art-based art education should be understood as a transfer of ways of thinking from art to education (Buschkühle, 2003, also see Alsaggar \& Shukran, 2014). This approach corresponds to processual aspect of art, the creation of relationships and situations, to an aesthetic-performative way of learning and to a sensory experience (Stutz, 2008) so the central issue in art education shifts from product to process.

Also, focus is on personal experiences, creativity and the message of the visual art. Within art itself, as well as within art education, social life forms may change. Students can use such personal experiences to create and broaden life opportunities and enhance their problemfinding and problem-solving abilities, that is creativity. Creativity is defined within the particular cultural context to which it contributes, and traditional models of education do not pay attention to the connection between individuals and their context (Helfand et al., 2016). The basic notion of contemporary visual art, is in the message that underlies the learning process in the domain of the visual art. Learning processes based on open-concept images include: image creation, observation, analysis and interpretation of image, reflection on contexts and processes related to images, content by which images become transmitters of meaning, themes, motifs, symbols, iconographic references, etc; emotional aspects and focus on students (Bering \& Niehoff, 2015). The life histories of those who create them are important, and the way they are perceived, experienced and interpreted depends on the observers and their life contexts (Bering \& Niehoff, 2015). 
Therefore, the proposed concepts of teaching art subjects in primary and secondary/ grammar school have a common starting point: the process as a one of the main characteristics in contemporary visual art, especially a participatory and new media art. Also, the concepts include (1) the curriculum as a process analogous to the creative process; a combination of information, lived experience and multiple meanings, as well as context; community learning and visual technologies, (2) transfer of processes from visual art creation to the creation processes in art classes, (3) transfer of ethical concepts from visual art topics (4) new media as a didactic tool.

\section{Research methodology}

\subsection{Primary school: application of the immersive method}

Immersive method (Vuk et al., 2015) is a concept of art education which involves the transfer of the creative process from visual art to the creation process of students and as a teaching approach.

Based on the results of the questionnaire collected in the quantitative research conducted in 2011/2012 on a random sample of 5th grade primary school students, $N=164$ and 8th grade primary school students, $\mathrm{N}=221$, it has been found that tasks in which creative process was checked was not completed by most of all students $\left(\chi^{2}(1,384)=2.625, p=0.105\right)$.

Based on the obtained results and by checking the initial state, action research was developed that included performative (Pfeil et al., 2010) and participatory research (Bergold \& Thomas, 2012) and conducted during the 2012/2013 academic year in three 5 th and three 8 th grades of primary school. The research encompassed 35 planned classes of fine arts subject according to the Curriculum for Fine Arts (Republika Hrvatska. Ministarstvo znanosti, obrazovanja i športa, 2006) and it lasted the entire academic year in three 5th and one 8th grade of primary school. Midway through its course, the research was discontinued in two 8th grades at the request of teachers. During an action research based on a 4-step developmental approach (Vogrinc, 2008), an immersive method was introduced by which the following is transferred from the contemporary visual art to the art education: 1. processual, participative and playful features, 2 . creative process that combines aesthetic, ethical and formal aspects by identifying and solving problems, by learning the ways to produce new ideas and transferring ideas to a form by means of materials and media, 3. equalizing the importance of the creative process and its results.

The sample of teachers specialized in teaching fine arts was $\mathrm{N}=4$. The sample of students with whom the research was fully conducted was 82 , and partially conducted $46(\mathrm{~N}=128)$. The sample was appropriate, the age of students was from 10 to 15 years of age.

Each action step corresponded to the project as a conceptual unit within which the teaching content was organized. The following changes were introduced in accordance with the action steps:

First action step: introduction of teaching methods and strategies, techniques for stimulating creative thinking and strategies of contemporary visual art in the formal aspect of tasks. These were introduced in the class using verbal, written and performing tasks and using communication technology (cell phones); 
Second action step: increasing intrinsic motivation in students, introducing clear rules for directing students' emotional and cognitive input into an appropriate form and medium by contemporary visual arts strategies;

Third action step: introducing self-assessment and self-reflection during the creative process;

Fourth action step: introducing partial autonomy of students in designing and managing their own projects: the teacher becomes a mediator, and the students adopt and independently apply the algorithmic scheme of the creative process; sensitivity to universal themes (independence in choice, sensitivity to context, empathic insight, flexibility, critical thinking towards the environment).

Each action step had common stages, which were partly carried out in the presented order, but also cyclically repeated and permeated:

1. Introducing a universal theme that raises moral and ethical issues. The problems of universal topics are taken from the objectives of the cross-curricular topics in the National Curriculum Framework for Preschool Education and General Compulsory and Secondary Education (Republika Hrvatska. Ministarstvo znanosti, obrazovanja i športa, 2011);

2. Linking a universal theme to a student's personal experience (generative theme);

3. Setting a work goal, producing more ideas, and selecting an idea that will be visualized;

4. Finding the right form for the given content or idea; selection of appropriate media and materials;

5. Reflection and analysis of process and results; elaboration and evaluation; remediation or formal reconstruction of visual works.

This paper presents only part of the action research which is directly related to the understanding of process and one objective from the whole research: to make progress with students in the following areas:

- understanding of the process of creation of contemporary visual art (finding problem in sociaty and offering solution for this problem by visual work);

- understanding the content of contemporary visual art and the ability to evaluate them;

- linking teaching content with real life;

- stimulating students' interest in moral and ethical issues (universal themes: truth, goodness, beauty) and their visual expression;

- shaping positive attitudes (by linking universal themes to generative themes in students' immediate reality);

- originality of ideas in visual expression;

- the use of new media and communication technology in the visual expression of students.

The research question for this part of the action research was as follows:

How to increase students' interest in visual expression with an emphasis on ideas and articulation of messages; adopting procedures for idea development, selecting the appropriate form for the given content; increasing the use of new media and new media strategies in visual expression; increasing students' interest in moral and ethical issues, the ability to evaluate their environment; forming positive attitudes and the ability to link the contents of visual works with real life; the ability to form original ideas in visual expression. 


\subsection{Grammar school: contemporary aspects of art}

Only a part of the experimental research with parallel groups of two classes of general course students on a sample of 120 students will be presented in this paper. Experimental research was conducted in the academic year of 2016/2017 and it focused on the discourse of the fine arts and visual arts and the connection of traditional artistic heritage with contemporary artistic practices. Consideration was given to establishing the relationship, order and continuity of the emergence, development and duration of modern, postmodern and contemporary art, and the transition and assimilation of the concept of fine art into the concept of visual art. The application of theoretical knowledge in the Art Theory classes is analyzed, as well as the review and redefinition of the concepts of high and popular culture. The purpose of the research was to examine contemporary art in school course programmes, that is, the role of new media within the teaching of fine and visual art in grammar schools. The research determined the real state of the art teaching practice as well as the development of guidelines for improving pedagogical practice. In the experimental part, the research of the Fine Arts curriculum in grammar schools was conducted by using the new media in order to get an answer as to whether the presence of new media contributes to the greater achievement of students in acquiring knowledge of fine arts. As an implication of this work, the desire was also to consider the possibility of developing fine art into a broader concept of the visual art.

General hypothesis. The assumption is that the introduction of new media in the teaching of educational content of fine and visual art will achieve statistically significant differences in the achievements of students in the knowledge of the content of fine art, which will be greater for students of the $\mathrm{E}$ (experimental) group relative to the $\mathrm{K}$ (control) group, which will be checked on the final test.

Special hypotheses. This paper presents only two specific hypotheses from the whole research:

1. The assumption is that there will be a significant statistical difference in students' achievements when comparing the results of the $\mathrm{E}$ and $\mathrm{K}$ groups in the final test as a whole, and by individual segments of the visual art questionnaire and new media in the visual art;

2. The assumption is that, based on the conducted research, there is a possibility to improve the teaching of Fine Arts subject, ie to redefine and re-shape the existing Fine Arts subjects into the Visual Culture in grammar schools.

The following methods were applied in the research: theoretical analysis method, descriptive method, experimental method with parallel groups, and statistical method. The choice is made by method of theoretical analysis, while the descriptive method was used to formulate: subjects, goals, tasks, hypotheses and methods of research, experimental factors, models, techniques and instruments of research, the size and characteristics of the samples of students in the research and the time of conducting the pedagogical experiment. The theoretical analysis method and the descriptive method were also used to review, study, analyze and document the current situation, and to make interpretations and descriptions.

After defining the research hypotheses, an independent variable was introduced, that is, an experimental factor presented as an innovative learning process in the experimental re- 
search group, using new media in the teaching of Fine Arts. Furthermore, the effect of the experimental factor on the quality of the acquired knowledge, achievements, motivation and interest of the experimental group students in acquiring new knowledge was monitored, as well as the possibility of transforming visual expression from traditional works of art into a new media visual art. For the purposes of preliminary analyses, the descriptive and frequency methods, the $\chi^{2}$ test and Pearson correlation coefficient were used. The instruments used in the research were tests for checking students' knowledge of $\mathrm{E}$ and $\mathrm{K}$ groups and a survey to determine attitudes and approaches in the work of teachers of Fine Arts in high schools. During the experimental study, E and K group students were tested on the initial test and final test.

The purpose of the initial test was to equalize the experimental and control groups based on the students' prior knowledge of the visual art. The initial test was related to the contents of the previously discussed subjects in the field of fine art during high school education in the 1st grade, according to the curriculum for the subject of Fine Arts for general and science course in grammar schools. The tests consisted of four subtests in the fields of: art theory, form theory, fine art history, contemporary art practice.

In addition to the content and the order of the teaching units, a clear presentation and insight into the introduction of new media in the teaching of the fine arts has been elaborated in detail in the lesson structure, as well as in the written lesson preparations for the lesson. The control group followed lesson units of art history classes in the traditional way, adhering to the content of the textbooks for the subject of fine arts, recommended by the educational authorities.

An innovative work program, implemented in the teaching of an E group of students, build up on the traditional artistic heritage as a starting point during the preparation of the lesson, and continued with the creative process of contemporary visual art practice. The works of contemporary art in correlation with the works of art from different historical periods were analyzed. In experimental teaching, digital forms of giffing, morphing, and mapping were also used as examples of the process of art-digital design in the visual art (Bosnar, 2018).

\section{Research results}

\subsection{Primary school}

The results of the questionnaire for 5th and 8th grade students, after the action steps concerning the reconstruction of the teaching and creative process, are presented here, as well as the results of tables for evaluating students' visual art works (rating rage from one to five).

First action step: in the 5th grade, the majority of students understood the course of the teaching process: out of the total number of answers $=49,39$ students $(79.6 \%)$ responded correctly to questions about non-verbal and visual communication. Three stages of the work process were successfully reconstructed by the majority of students: 40 students (81.6\%) answered correctly "First we wrote"; "Then we wrote", more than half of the students answered correctly (29 students, 59.2\%) and partially correct (15 students, 30.6\%); "We visualized the written word by" less than a third of students answered correctly (14 students, 28.6\%), and a third of students answered partially correct (16 students, 32.7\%). Almost all students 
answered the following question about remote associations (46 students, 93.4\%). The majority of students $(33,67.3 \%)$ gave the correct explanation for the question "What did these words serve us for?". They were also familiar with what contemporary media they were using (81.6\%).

The results of the evaluation tables of students' visual art works (number of students is 52) show that the best scores were achieved in originality (average value 4.35, standard deviation 1.24), conceptual thinking and transfer of ideas into form (average value 3.88, standard deviation 1.26), variations in the process of transferring ideas into form (average value is 3.81 , standard deviation 1.36), perception of the whole or details of the subordinate entity (average value 3.88, standard deviation 1.26), and completion of works as a realization of ideas in a form, medium and material (average value 3.62, standard deviation 1.52). Also, relatively highly rated are: reflection on one's own creative process (average value 3.85, standard deviation 1.30), process-participation acceptability (average value 3.71, standard deviation 1.33), and reaction to criticism (teacher and co-students) during the creative process (average value 3.87, standard deviation 1.30).

In the 8th grade (total answers $=70$ ), a process was to be reconstructed in which the stories that served the script were the end result. 16 students answered correctly (22.9\%), and partially correctly (27 students, 38.6\%). When asked what they wrote afterwards, 28 students (40\%) answered correctly, and 12 students (17.1\%) answered partially correctly. When asked what kind of communication they wrote the script for, 14 students (20\%) answered correctly, and 19 students $(27.1 \%)$ answered partially correctly. When asked what topics they visualized, more than half of the students answered this question correctly (36 students, 51.4\%), and 3 students (4.3\%) answered partially correctly. The results of the evaluation tables for students' visual art works (56 students) show that the most common score is 4 on the criteria of originality (average value 4.21, standard deviation 0.73 ), willingness to be guided through the creative process (average value 4.16, standard deviation 0.71 ), handling of techniques and materials (average value 4.20, standard deviation 0.62 ), variations in application (average value 4.13 , standard deviation 0.69 ), technical skills (average value 4.14, standard deviation 0.59 ) and work completion (average value 4.46, standard deviation 1.04). The best scores are in reaction to criticism (average value 4.91, standard deviation 0.35 ) and reflection of one's own creative process (average value 4.71, standard deviation 0.56).

Second action step: in the 5th grade (total answers $=49$ ), more than three quarters of the students correctly answered the question what they were writing the story about $(33,77.6 \%)$, and 9 answers (18.4\%) were partially correct. More than half of the students correctly answered the question that evokes performance as a strategy of new media art and everyday environment and deals with the artistic form of performance (29,59.2\%), and 2 answers were partially correct (4.1\%). The results of the evaluation charts of students' visual art work (51 student) show the best scores in reaction to criticism (no one has received a rating lower than 5), in understanding and applying key concepts (average value 4.96, standard deviation 0.20 ) and in reflecting one's own creative process (average value 4.92, standard deviation 0.27).

In 8th grade (total answers $=37$ ), in the task in which students were to describe the course of the entire work process, the largest number of students correctly answered the question what they wrote first $(26,70.3 \%)$ and the question what they got afterwards $(17,45.9 \%)$. 
More than half of the students responded to the following two steps correctly $(19,51.4 \% ; 21$, $56.8 \%$ ). The results of the evaluation charts for students' visual art works (44 students) show that the best scores are in reaction to criticism and in receptivity to guidance through the creative process. Relatively, the lowest average score (although above grade 4) is in originality.

Third action step: in 5th grade (total answers $=56$ ), the first stage of work was recognized and defined by an equal number of students who answered correctly $(22,39.3 \%)$ and those who answered partially correctly $(21,37.5 \%)$. The second stage was recognized and defined by the largest number of students $(35,62.5 \%)$ and partially by $10(17.9 \%)$, while the third stage was recognized by the largest number of students $(24,42.9 \%)$, but a quarter of them responded partially correctly $(14,25 \%)$. The results of the evaluation tables for students' visual art works show that in Task 1 (number of groups $=11$ ), all grades are 5 (no inter-group variability). Scores 3 and 4 appear for originality (average value $=4.36$, standard deviation $=$ 0.81 ) and variation in the process of translating ideas into form (average value $=4.73$, standard deviation $=0.65$ ). In Task 2 (number of pairs $=25$ ), the most common grade of is 5 . And on the following criteria, all students received a grade of 5: understanding and applying key concepts, reflecting on their own creative process, willingness to be lead through the process, responding to criticism, handling techniques and materials, variations in application. Other values are as follows: conceptual thinking (average value $=4.56$, standard deviation $=$ 0.65 ), variations in the transfer of ideas to form (average value $=4.72$, standard deviation $=$ 0.46 ), originality (average value $=4.64$, standard deviation $=0.49$ ), perception of the whole issue (average value $=4.64$, standard deviation $=0.57$ ), technical skills (average value $=4.96$, standard deviation $=0.20$ ), completion of works (average value $=4.36$, standard deviation $=$ 0.86). In Task 3 (number of groups $=9$ ), all grades are 5, including grades for group work. There is no inter-group variability.

In the 8th grade (total answers $=25$ ), in the group of questions dealing with the understanding of workflow, almost half of the students gave the correct answer for the first stage $(12,48 \%)$, and one third gave the partially correct answer $(8,32 \%)$. Most students correctly answered the question about the second stage in which the storyboard was drawn $(22,88 \%)$, and almost all students defined the third stage of the work accurately (23, 92\%). In the question concerning strategies of the new media environment and visual art, students were expected to choose from the offered terms those which they would apply to the work in the video medium. Suspense was chosen by 3 ( $12 \%$ of students), interactivity 8 ( $32 \%$ of students) and action 16 (64\% of students). The majority of students correctly answered the question that dealt with recognizing the theme of the project $(71.4 \%)$. When asked by which art mediums they expressed the given problem related to the general theme of inequality between people, almost all students out of 25 answered correctly $(24,98 \%)$. In terms of the issue itself, or the name of the Universal Declaration of Human Rights, which was the starting point of their own stories, the majority of students answered correctly $(22,88 \%)$. The results of the evaluation charts of students' visual art works (25 students in 3 groups) show that all groups on all evaluation criteria received a grade of 5 (no variability in the evaluation of the works).

Fourth action step: in 5th grade (total answers = 51), two questions dealt with the universal theme and linking the universal theme with the idea of students' work. When asked what students needed to express using composition of figures and space, the largest number of students answered correctly $(31,60.8 \%)$, and the universal theme was recognized by almost 
two thirds of students $(33,64.7 \%)$. The results of the spreadsheets for evaluating students' visual art works by schools are: 1 st school ( 24 students), almost all grades are 5 (no variability among students); 2nd and 3rd schools (number of groups $=5$ ), almost all grades are 5 (no variability among students), including the grade for group work. Only two grades 4 appear in the criterion of work completion (average value $=4.60$, standard deviation $=0.55$ ).

In 8 th grade (total answers $=24$ ), all students answered correctly that they had done sketches for the graffiti medium (24,100\%). Questions that addressed the understanding of the work process: the common theme of a visual assignment, more than three-quarters of students answered correctly $(19,79.2 \%)$. In questions that tested the understanding of the universal themes, two-thirds of students correctly answered the question about what stereotypes were, using their own words $(16,66.7 \%)$, and three-quarters of students answered correctly what prejudices were $(18,75 \%)$. The results of the evaluation tables for students' visual art works (24 students) show that the best grades are in reaction to criticism (all students received a grade of 5) and in understanding and applying key concepts. Relatively low average scores (though above 4) are in variations in the process of transferring ideas to form and originality.

\subsection{Grammar school}

Table 1 shows the results of the students of both groups after the final test, and on the sample of 120 students who were in the teaching process, 103 students were examined at the final test. The differences in the final test of the answers of $\mathrm{K}$ and $\mathrm{E}$ group of students can be traced by groups of questions about art theory, new media art practice, art history and contemporary art in general. By a comparative analysis of the results of the experimental $\mathrm{E}$ and the control group $\mathrm{K}$ of the initinal testing, the uniformity of the results is evident. A significant difference in the acquired knowledge in the final testing sections is in favour of the experimental E group of students who attended the classes according to the innovative program. According to the result of the final testing, the experimental E group, following the innovative teaching, adopted knowledge in contemporary visual and other visual arts including new media art practices where $(\mathrm{r}=0.78$, Table 1$)$.

Table 1. Correlations between the total score and the sections of the initial test (IT) and final test (FT) (source: created by authors)

\begin{tabular}{|l|l|c|c|c|c|c|c|c|c|}
\hline \multicolumn{2}{|c|}{} & 1 & 2 & 3 & 4 & 5 & 6 & 7 & 8 \\
\hline \multirow{4}{*}{ IT } & Art theory (1) & & & & & & & & \\
\cline { 2 - 11 } & Form theory (1) & 0.22 & & & & & & & \\
\cline { 2 - 12 } & Fine art history & 0.34 & 0.35 & & & & & & \\
\cline { 2 - 11 } & Total (4) & 0.51 & 0.60 & 0.94 & & & & & \\
\hline \multirow{5}{*}{ FT } & Art theory (5) & 0.23 & 0.19 & 0.23 & 0.28 & & & & \\
\cline { 2 - 11 } & New media art practice (6) & 0.05 & 0.15 & 0.24 & 0.24 & 0.67 & & & \\
\cline { 2 - 11 } & Art history (7) & 0.07 & 0.20 & 0.32 & 0.32 & 0.72 & 0.83 & & \\
\cline { 2 - 10 } & Contemporary art (8) & -0.06 & 0.07 & 0.19 & 0.16 & 0.58 & 0.75 & 0.78 & \\
\cline { 2 - 10 } & Total (9) & 0.07 & 0.16 & 0.29 & 0.28 & 0.79 & 0.94 & 0.95 & 0.86 \\
\hline
\end{tabular}




\section{Discussion}

The primary school action research dealt with the reconstruction of the creation of contemporary visual art and the transfer of this process into the art classes. The teaching process included equalizing the importance of the creative process and results, developing students' creative and critical thinking, sensitivity for moral and ethical issues that is for finding the problems in society and offering the solutions through visual art work, using new media and communication technology as media equal to traditional art media, introducing visual arts strategies into the formal aspect of creation, and as an approach to learning and teaching. Based on the assessment of the initial state, the goal was to make progress in the creative and critical thinking of the students, to know the peculiarities of contemporary visual art in terms of moving away from the artifact into living matter or process, transferring the stages of the creative process from artistic creation to student's creativity, adopting ways to produce ideas and transfer ideas into appropriate form through materials and media, and communication with the environment through visual expression. In doing so, students needed to offer solutions to social, moral and ethical issues, which emphasized the personal growth of students. The obtained results show the purpose of applying the immersive method, which is to actively involve students in their own life context and to positively change that context through creativity.

The results of the educational process created by the immersive method confirm that learning and creativity share many similarities, therefore the learning process can be structured according to the stages of the creative process (Truman, 2011). The didactic approach in the immersive method transfers the stages of the creative process into the learning process, then transfers the methods and strategies from the arts to the teaching process, and uses teaching methods and strategies not only in the educational process but also in the creative process. The aim of this approach is to stimulate the growth of a complete person, which can be achieved through integrated education (Read, 2002). In doing so, teaching becomes a creative process because learning and teaching are conceptualized as a shared reflectivetransformative practice (Ritchart et al., 2011).

Experimental research in secondary school-grammar school in accordance with the results of pretesting, the operative plan and program of experimental research established not only the discourse of contemporary and traditional artistic creation through new media, but also the uniform ratio of the representation of theoretical and practical artistic fields from which artistic creation is contemplated. In the program, which was created and applied in the teaching process of the experimental part of the research, the contents from the theory of art, theory of form and history of art and the actual practice of art are harmonized.

The innovative approach to teaching has affirmed contemporary creativity, and in particular its process of creating, as a starting point for understanding the idea, theme and message of the work of art in the context of the time in which it is presented through the medium. Digital processes, the transfer of analogue to digital format, which was affirmed in the course of teaching about the importance and role of film, photography, graphic design, game design, the field of visual and applied arts whose cover term becomes visual art/culture (Bosnar, 2018). 
Contemporary artistic practices are not only a process of artistic creation, but also a process of teaching and learning in teaching, of art in general education. Teaching and learning about new media practice took place through arrangement of video art topics, video game design, animation, mapping, and more. Recognition of visual speech was sought by students through the analogy of painting discourse and pictorial values in relation to the visual communications of digital media.

Majority of the students...

...in elementary school:

- succeed reconstruction of the creative process;

- recognized universal theme as a starting point of the creative process;

- made connection between the universal theme and personal experience (generative theme);

- applied knowledge of visual language and medium on the reconstruction of the process.

...in grammar school:

- understood the idea, theme and message of the art work in the context of the time and the medium;

- understood visual language through the analogy of painting discourse and pictorial values of digital media.

\section{Conclusions}

Applying the immersive method as a way of transferring the stages of the creative process from the creation of contemporary visual art to the creativity of elementary school students, offers a systematic development of students' creativity and perception. Structured learning of the creative process is made possible by personalized learning, starting point in social, ethical and moral topics which are also actual in contemporary visual art, developing ideas for solving the given problem, and a formal solution in the medium as the transmission of information or message. The algorithmic approach has been taken from the new media environment of students, because new media, as an important means of today's students socializing, affect their relationships, so they need to be creatively applied. Understanding the creation of visual art and culture comes not from analysis, but reconstruction of the accomplished process and equalizing the importance of the process and the product. In line with the nature of creativity, which is more a process than an event, such an approach involves emotions, context, thought processes such as analytical and synthetic thinking, and relational thinking that creates new relationships. Creative expression thus becomes the medium of interaction between students and their environment, and the focus shifts to the social quality of learning about the visual art, as well as it is in participatory art. In doing so, the cognitive processes necessary to cope with modern society and the growth of the complete person are being developed.

The teaching of fine art and visual art in grammar school, ensures a continuous process of cultivating an awareness of the general culture, and especially the formation of attitude that will follow the true values of artistic creativity. Visual sensations that correspond with young people and adults open up numerous cognitive possibilities of the visible world around us. The rise of digital technology is often interpreted as the subjugation of the visual arts to 
a popular culture that is semantically commercial and accessible to all. For this reason, new media, have been selected for consideration in the teaching of fine arts in high schools grammar schools from two perspectives: (1) new media as an only didactic tool that students can be taught by and (2) about new media art practice. It is only through new media didactic tools that it is possible to monitor, view, understand and practice new media art, either through the dimension of high art or from the point of view of popular culture. This unique process of artistic creativity also encourages the development of mental and intellectual processes by understanding new technologies and artistic media in a social context.

Two different approaches presented in this article shift the central issue in art education from what to how, i.e. on the process. In this way, visual art has a pedagogical role in developing ethical beauty and an even better understanding of the social and political relations of the world in which students grow up.

\section{References}

Alsaggar, M. A., \& Shukran, Q. A.-K. (2014). Interdisciplinary art education. International Journal of Elementary Education, 3(3), 81-85. https://doi.org/10.11648/j.ijeedu.20140303.15

Baudrillard, J. (2006). Inteligencija zla ili pakt lucidnosti. Naklada Ljevak d.o.o.

Bergold, J., \& Thomas, S. (2012). Participatory research methods: a metodological approach in motion. Forum: Qualitative Social Research. Socialforschung, 13(1). https://www.qualitative-research. net/index.php/fqs/article/view/1801/3335

Bering, K., \& Niehoff, R. (2015). Visual proficiency: A perspective on art education. Athena Verlag.

Bosnar, M. (2018). Suvremena umjetnost u obrazovanju: uloga novih medija u nastavi likovne kulture u gimnazijama. Akademija likovnih umjetnosti.

Buschkühle, C.-P. (Hrsg.). (2003). Perspektiven künstlerischer Bildung. Salon Verlag.

Carroll, N. (1998). A philosophy of mass art. Oxford University Press.

Freedman, K. (2003). Teaching visual culture: curriculum, aesthetics, and the social life of art. Teachers College Press.

Groys, B. (2006). Učiniti stvari vidljivima: strategije suvremene umjetnosti. Muzej suvremene umjetnosti.

Helfand, M., Kaufman, J. C., \& Beghetto, R. A. (2016). The Four-C model of creativity: culture and context. In V. P. Glăveanu (Ed.), The Palgrave handbook of creativity and culture research. Series: Palgrave Handbooks (pp. 15-36). Palgrave Macmillan. https://doi.org/10.1057/978-1-137-46344-9_2

Kettel, J. (Hg.). (2004). Künstlerische Bildung nach Pisa. Internationale Gesellschaft der Bildenden Künste (IGBK)/Landesakademie Schloß Rotenfels (Hgg.), u.a. mit Ch. Biehler, Ch. Jürgens, I. Merkel, K.-J. Pazzini, \& H. Seitz. Athena Verlag.

Kirby, A. (2009). Digitmodernism: How new technologies dismantle the postmodern and reconfigure our culture. The Continuum International Publishing Group.

Milevska, S. (2006). Participatory art: a paradigm shift from objects to subjects. Eurozine. https://www. eurozine.com/participatory-art/?pdf

Pfeil, M., Seitz, H., \& Vogt, Ch. (2010). Be unique, be open, be art. In Building bridges, breaking borders: urban culture and youth. Urban culture and youth in Berlin and beyond, or how to do things with art (pp. 51-127). SWP.

Read, H. (2002). To hell with culture, and other essays on art and society. Routledge. 
Republika Hrvatska. Ministarstvo znanosti, obrazovanja i športa. (2011). Nacionalni okvirni kurikulum za predškolski odgoj i obrazovanje te opće obvezno i srednjoškolsko obrazovanje. Republika Hrvatska. Ministarstvo znanosti, obrazovanja i športa.

Republika Hrvatska. Ministarstvo znanosti, obrazovanja i športa. (2006). Nastavni plan i program za osnovnu školu. Narodne novine: službeni list Republike Hrvatske. https://narodne-novine.nn.hr/ clanci/sluzbeni/full/dodatni/129167.pdf

Ritchart, R., Church, M., \& Morrison, K. (2011). Making things visible: how to promote engagement, understanding, and independance for all learners. Jossey-Bass.

Stanković, M. (2014). Participativne prakse u srpskoj savremenoj umetnosti. Kultura, 143, 297-318. https://doi.org/10.5937/kultura1443297s

Strehovec, J. (2003). Umetnost interneta: umetniško delo in besedilo v času medmrežja. Študentska založba.

Stutz, U. (2008). Performative research in art education: scenes from the seminar "Exploring performative rituals in city space". Forum: Qualitative Social Research. Socialforschung, 9. https://www. qualitative-research.net/index.php/fqs/article/view/411/894

Šuvaković, M. (2012). Pojmovnik teorije umetnosti. Orion Art.

Truman, S. (2011). A generative framework for creative learning: a tool for planning creative-collaborative tasks in the classroom. Border Crossing: Transnational Working Papers, 1101. https://doi.org/10.33182/bc.v1i1.518

Vogrinc, J. (2008). Kvalitativno raziskovanje na pedagoškem področju. Univerza v Ljubljani.

Vuk, S., Tacol, T., \& Vogrinc, J. (2015). Adoption of the creative process according to the immersive method. Center for Educational Policy Studies Journal, 5(3), 51-71. 